\title{
ANALISIS EKONOMI PEMANFAATAN JUS LIMBAH WORTEL (Daucus Carota L.) SEBAGAI FEED SUPPLEMENT TERNAK AYAM KAMPUNG
}

\author{
Hasrianti Silondae \\ Vicky Ventje Johan Panelewen \\ Jolanda Kitsia Juliana Kalangi
}

\begin{tabular}{ll}
\hline Naskah diterima melalui Website Jurnal Ilmiah agrisosioekonomi@unsrat.ac.id & : Selasa, 26 November 2019 \\
Disetujui diterbitkan & $:$ Kamis, 28 November 2019 \\
\hline
\end{tabular}

\begin{abstract}
This study aims to determine the economic feasibility of utilizing carrot juice (Daucus carota L.) as feed supplement for native chicken. The study was conducted from April to July 2019 in the Pandu Experimental Garden in North Minahasa Regency. Economic analysis in the form of income analysis to determine the income derived from the livestock business by raising native chickens. If the value of TR> TC, the livestock business is profitable, if $T R=T C$, the livestock business is in a BEP condition, and if $T R<T C$, the livestock business loses. Business feasibility analysis includes price BEP, production BEP and $R / C$ ratio. The results showed that the utilization of carrot juice (Daucus carota L.) as a feed supplement for native chicken livestock is economically feasible to be cultivated because it provides benefits based on economic analysis of $R / C$ value $>1$ and Break Event Point that is exceeded by product income and rupiah. ${ }^{*}$ prm*
\end{abstract}

Keywords: carrots; Kampong chicken; $R$ / C ratio

\begin{abstract}
ABSTRAK
Penelitian ini bertujuan untuk mengetahui kelayakan ekonomi pemanfaatan jus limbah wortel (Daucus carota L.) sebagai feed supplement untuk ternak ayam kampung. Penelitian dilaksanakan pada bulan April sampai dengan bulan Juli 2019 di Kebun Percobaan Pandu Kabupaten Minahasa Utara. Analisis Ekonomi berupa analisis pendapatan untuk mengetahui pendapatan yang diperoleh dari usaha ternak tersebut dengan pemeliharaan ayam kampung. Apabila nilai TR > TC maka usaha ternak menguntungkan, apabila TR=TC maka usaha ternak dalam kondisi BEP, dan apabila TR < TC maka usaha ternak rugi. Analisis kelayakan usaha meliputi BEP harga, BEP produksi dan R/C ratio. Hasil penelitian menunjukkan bahwa pemanfaatan jus limbah wortel (Daucus carota L.) Sebagai feed supplement ternak ayam kampung layak secara ekonomi untuk diusahakan karena memberikan keuntungan berdasarkan analisis ekonomi nilai R/C >1 dan Break Event Point yang dilampaui oleh penghasilan produk dan rupiahnya. ${ }^{*}$ eprm*
\end{abstract}

Kata Kunci: wortel; ayam kampung; R/C ratio 


\section{PENDAHULUAN}

\section{Latar Belakang}

Ayam kampung adalah salah satu sumber plasma nutfah hewani yang layak untuk dikembangkan. Ayam kampung dikenal sebagai jenis unggas yang mempunyai sifat dwi fungsi, yaitu sebagai ayam petelur dan ayam potong. Ayam kampung merupakan salah satu sumber protein hewani dan dikenal keberadaannya karena telah menjadi bagian kehidupan masyarakat Indonesia terutama di pedesaan (Setyanto, et al. 2012).

Secara umum kebutuhan gizi untuk ayam, paling tinggi selama minggu awal (0-8 minggu), oleh karena itu perlu diberikan pakan yang cukup mengandung energi, protein, mineral dan vitamin dalam jumlah yang seimbang. Faktor lainnya adalah perbaikan genetik dan peningkatan manajemen pemeliharaan ayam lokal harus didukung dengan perbaikan nutrisi pakan. Kebutuhan energi termetabolis ayam tipe ringan umur 2-8 minggu antara $2.600-3.100 \mathrm{kkal} / \mathrm{kg}$ dan protein pakan antara $18,0 \%-21,4 \%$, sedangkan menurut NRC (1994) kebutuhan energi termetabolis $2.900 \mathrm{kkal} / \mathrm{kg}$ dan protein $18,0 \%$.

Indonesia merupakan negara yang subur dan memiliki sumber daya alam yang sangat potensial sehingga untuk mencapai ketahanan pangan nasional perlu dikembangkan sumber daya dan potensi lokal. Hasil pertanian dan perkebunan yang melimpah kadang menyisakan dampak negatif bagi lingkungan, terutama kegiatan yang dilakukan makhluk hidup banyak menghasilkan limbah. Di Indonesia, sampah organik seperti sayursayuran (contohnya wortel, kubis, kol, kentang, selada air, kangkung, dan sawi) ataupun buahbuahan (kulit pisang, kulit nenas, kulit jeruk) biasanya dimanfaatkan untuk makanan kelinci, kambing, ayam, atau itik. Hal ini sangat menguntungkan karena selain mengurangi jumlah sampah, juga mengurangi biaya pakan untuk hewan ternak. Sampah organik yang mudah rusak dapat dimanfaatkan untuk makanan ternak. Produktivitas ternak sangat dipengaruhi oleh ketersediaan pakan, baik secara kualitas maupun kuantitas. Biaya pakan yang mahal membutuhkan sentuhan inovasi dan alternatif yang bisa dijangkau oleh para peternak. Salah satu gagasan yang dapat mendukung keberlangsungan ketersediaan sumber hewani berupa daging dan telur di samping upaya menjaga lingkungan yaitu dengan memanfaatkan limbah sayuran yang sangat banyak tersedia di pasar. Salah satu limbah yang cukup potensial adalah sayur wortel yang potensial dikembangkan sebagai feed supplement bagi ternak ayam kampung. Diketahui bahwa wortel merupakan sayuran akar dengan senyawa bioaktif seperti karotenoid dan serat makanan dengan kadar yang cukup dari beberapa komponen fungsional lain yang dapat meningkatkan kesehatan secara signifikan (Sharma et al. 2011). Dutta (2005) dalam Kusbandari dan Susanti (2017) menjelaskan bahwa betakaroten merupakan pigmen organik berwarna kuning, oranye atau merah oranye yang dapat terjadi secara alamiah dalam tumbuhan yang berfotosintesis, ganggang, beberapa jenis jamur dan bakteri. Betakaroten dapat larut dalam lemak, tidak larut dalam air, mudah rusak karena teroksidasi pada suhu tinggi. Betakaroten memiliki potensi sebagai prekursor vitamin A dalam mempertahankan kesehatan mata dan integritas membran sel yang menjadikan senyawa ini bersifat vital bagi tubuh. Selain itu, karotenoid berperan sebagai prekursor retinol dan retinoid yang penting untuk kesehatan manusia yaitu dapat mencegah serangan oksidasi melalui potensinya sebagai peredam oksigen singlet (Winarsih, 2007:161). Wortel dapat tumbuh dengan baik hampir di seluruh Indonesia, sehingga bahan baku wortel mudah dicari. Hal ini tentu saja dapat memudahkan produksi karena ketersediaan bahan baku dan harganya yang terjangkau. Produksi yang berlebihan kadang menjadikan sayur wortel dengan kualitas buruk dibuang begitu saja sehingga turut mencemari lingkungan. Langkah strategis mengatasi persoalan tersebut, menjadi alasan penulis melakukan penelitian pemanfaatan limbah wortel yang diharapkan dapat memunculkan alternatif pakan atau feed supplement yang bisa diberikan pada air minum ayam kampung dan layak secara ekonomi untuk diusahakan oleh para peternak. 


\section{Deskripsi dan Kebutuhan Nutrisi Ayam Kampung}

Peternakan di Indonesia seiring berjalannya waktu mulai mengalami peningkatan dalam berbagai sektor kehidupan (Tahalele, 2018). Keadaan ini didorong oleh meningkatnya kesadaran masyarakat akan kebutuhan gizi yang bersumber dari hewani, salah satunya berasal dari daging ayam kampung. Demikian pula warta dari Direktorat Jendral Peternakan (2015), menyatakan bahwa Indonesia memiliki berbagai sumberdaya genetik diantaranya ayam lokal yang mempunyai potensi tinggi untuk membangun peternakan nasional. Ayam lokal dikenal masyarakat umum sebagai ayam kampung atau ayam buras, populasinya cukup tinggi yaitu 285.021.084 ekor yang mampu menyumbang daging sebesar 297,65 ribu ton atau $10 \%$ dari total produksi daging, dengan produksi telur sebesar 184,64 ribu ton atau $10 \%$ dari total produksi telur. Ada 22 juta rumah tangga pertanian yang memiliki ternak ayam lokal/kampung (1-30 ekor) dan hampir 1 juta rumah tangga pertanian yang memiliki usaha ternak ayam lokal (30 ekor ke atas). Dalam delapan tahun terakhir, berkembang pesat usaha peternakan unggas lokal pola semi intensif dan intensif dengan kepemilikan 500 ekor - 150.000 ekor.

Ayam lokal dikenal sebagai ternak yang mempunyai daya hidup yang tinggi, dapat hidup diberbagai wilayah dengan perbedan kondisi iklim yang ekstrim, mempunyai kemampuan untuk hidup dalam kondisi pakan dengan kandungan nutisi yang rendah, Hasil produksi ayam kampung berupa telur dan daging sangat digemari masyarakat. Contohnya untuk keperluan minuman tambahan pada jamu maka telur ayam kampung merupakan unsur keharusan dipergunakan. Dagingnya sampai saat ini belum dapat tersaingi oleh daging ayam pedaging. Bagi masyarakat kecil dan petani/peternak ayam kampung merupakan sumber tabungan. Sewaktu-waktu ayam tersebut maupun telurnya dapat ditukarkan atau dijual untuk dijadikan uang tunai.
Ternak ayam kampung merupakan salah satu jenis ternak unggas yang telah memasyarakat dan tersebar diseluruh pelosok nusantara. Ayam kampung memiliki banyak varietas dan spesies, beberapa diantaranya yang penting yaitu: Ayam Kedu. Ayam kedu merupakan ayam lokal yang berkembang di Kabupaten Magelang dan Temanggung, eks Karesidenan Kedu di Jawa Tengah. Berdasarkan penampilan warnanya, ayam kedu dapat dibedakan menjadi empat jenis, yaitu: Ayam Kedu Hitam, Ayam Kedu Cemani, Ayam Kedu Putih, Ayam Kedu Merah Ayam Nunukan, disebut juga Ayam Tawao. Ayam ini merupakan ayam lokal yang berkembang di pulau Tarakan, Kalimantan Timur. Ayam Nunukan diperkirakan berasal dari Cina. Stadium anak ayam sampai umur 45 hari cenderung berbulu kapas. Berat badan Ayam Nunukan jantan dewasa 3,4 kg-4,2 kg, sedangkan yang betina 1,6$1,9 \mathrm{~kg}$. Ayam Pelung merupakan ayam lokal yang berkembang di Kabupaten Cianjur dan Sukabumi (Jawa Barat). Ayam Pelung memiliki sosok tubuh besar dan tegap, temboloknya tampak menonjol. Kakinya panjang, kuat dan berdaging tebal. Ayam pelung jantan dewasa memiliki bobot badan berkisar antara $3,5 \mathrm{~kg}-5 \mathrm{~kg}$ dan yang betina 2,5 kg- 3,5 kg. Ayam Sumatera merupakan ayam lokal dari Sumatera Barat. Ayam Sumatera memiliki jengger berbentuk wilah dan berwarna merah atau hitam, ditumbuhi bulu halus yang jarang. Bobot ayam Sumatera jantan dewasa 2 $\mathrm{kg}$, sedangkan yang betina $1,5 \mathrm{~kg}$. Ayam Gaok berasal dari Madura dan Pulau Puteran, Kabupaten Sumenep. Ayam Gaok dewasa memiliki bobot badan mencapai $4 \mathrm{~kg}$, sedangkan yang betina 2-2,5 kg. Ayam Gaok jantan memiliki tampilan tubuh besar, tegap dan gagah. Jenggernya besar membentuk wilah dan berwarna merah, dengan pial yang besar dan warnanya merah. Ayam Jawa Super atau Ayam Silangan adalah hasil kawin silang antara Ayam Kampung dengan Ayam Layer Petelur Ras.

Ayam kampung yang banyak dipelihara sekarang ini secara genetis diperkirakan berasal dari keturunan ayam hutan merah (Gallus gallus) dan ayam hutan hijau (Gallus varius). Akibat proses budidaya dan pengaruh lingkungan hidup yang berbeda-beda, terbentuklah beragam varietas dan tipe ayam. Masing-masing memiliki fisik dan sifat genetik

Agrisosioekonomi:

Jurnal Transdisiplin Pertanian (Budidaya Tanaman, Perkebunan, Kehutanan, Peternakan, Perikanan), Sosial dan Ekonomi 565 
yang berbeda. Kelompok Gallus domesticus ini dibedakan menjadi ayam buras (ayam kampung) dan ayam ras (Iswanto, 2008). Ayam buras dengan kata lain ayam bukan ras merupakan jenis ayam yang banyak dipelihara orang di Indonesia, terutama di daerah pedesaan. Banyak nama dipakai untuk menyebut ayam itu. Taksonomi ayam kampung adalah Filum: Chordata, Subfilum: Vertebrata, Class: Aves, Subclass: Neornithes, Ordo: Galliformes, Genus: Gallus, Spesies: Gallus domesticus (Williamson dan Payne, 1993). Dibandingkan dengan ayam ras, ayam kampung juga jauh lebih lincah dan aktif bergerak. Jika dipelihara secara umbaran, terbiasa hinggap atau istirahat di dahan pohon yang cukup tinggi. Selain itu, ukuran tubuhnya juga lebih kecil dibandingkan dengan ayam ras (Sarwono, 1996). Keistimewaan ayam buras adalah tahan terhadap pengelolaan yang buruk, tidak peka terhadap kadar amoniak yang tinggi, dapat diberikan pakan kualitas yang kurang baik serta tidak mudah stress bila mendapat perlakuan yang kasar. Sedangkan kendalanya adalah sangat rendah produktivitas dan tanggapannya terhadap makanan yang berkualitas sangat minim, sehingga sangat ekonomis bila cukup diberi pakan murah atau sedang sebagai penghasil daging dan telur (Murtidjo, 1985).

Ayam kampung mempunyai kelebihan pada daya adaptasi tinggi karena mampu menyesuaikan diri dengan berbagai situasi, kondisi lingkungan dan perubahan iklim serta cuaca setempat. Ayam kampung memiliki bentuk badan yang kompak dan susunan otot yang baik. Bentuk jari kaki tidak begitu panjang, tetapi kuat dan ramping, kukunya tajam dan sangat kuat mengais tanah. Ayam kampung penyebarannya secara merata dari dataran rendah sampai dataran tinggi (Rasyaf, 1992). Salah satu ciri ayam kampung adalah sifat genetiknya yang tidak seragam. Warna bulu, ukuran tubuh dan kemampuan produksinya tidak sama merupakan cermin dari keragaman genetiknya. Di samping itu badan ayam kampung kecil, mirip dengan badan ayam ras petelur tipe ringan (Rasyaf, 2001). Ayam kampung memiliki kelebihan yaitu lebih tahan terhadap cekaman dan dagingnya disukai terutama untuk olahan tertentu. Daging ayam kampung memiliki kandungan protein yang tinggi yaitu $18,1 \%$. Ayam kampung disukai orang karena dagingnya yang kenyal, tahan pengolahan (tidak hancur ketika dimasak) dan "berisi", tidak lembek dan tidak berlemak sebagaimana ayam ras, kandungan nutrisinya yang lebih tinggi. Dagingnya mengandung 19 jenis protein dan asam amino yang tinggi, kadar lemaknya juga relatif lebih rendah daripada ayam broiler. Sebagai sumber protein hewani, telur dan daging ayam kampung mengandung asam amino esensial yang sangat dibutuhkan oleh tubuh dan berperan dalam meningkatkan kesehatan masyarakat. Kekurangan ayam kampung adalah perkembangbiakkannya lambat, pertumbuhan lambat, dan kerangka tubuh kecil sehingga pertumbuhan daging memerlukan waktu yang lebih lama (Hardjosworo dan Rukmiasih, 2000). Beberapa kebiasaan atau sifat ayam kampung yang merugikan, diantaranya yaitu: kanibalisme, mematuk, bahkan memakan kawan sendiri. Memakan telur (egg eating) sering dijumpai pada pemeliharaan ayam sistem kandang litter.

Secara umum, kebutuhan gizi untuk ayam paling tinggi selama minggu awal (0-8 minggu) dari kehidupan, oleh karena itu perlu diberikan ransum yang cukup mengandung energi, protein, mineral dan vitamin dalam jumlah yang seimbang. Faktor lainnya adalah perbaikan genetik dan peningkatan manajemen pemeliharaan ayam kampung harus didukung dengan perbaikan nutrisi pakan (Setioko dan Iskandar, 2005). Sampai saat ini standar gizi ransum ayam kampung yang dipakai di Indonesia didasarkan rekomendasi Scott et al (1982) dan NRC (1994). Menurut Scott et al (1982) kebutuhan energi metabolis ayam tipe ringan umur 2-8 minggu antara 2600-3100 $\mathrm{kkal} / \mathrm{kg}$ dan protein pakan antara $18-21,4 \%$ sedangkan menurut NRC (1994) kebutuhan energi metabolis dan protein masing-masing $2900 \mathrm{kkal} / \mathrm{kg}$ dan 18\%. Standar tersebut sebenarnya adalah untuk ayam ras, sedangkan standar kebutuhan energi dan protein untuk ayam kampung yang dipelihara di daerah tropis belum ada. Oleh sebab itu, kebutuhan energi dan protein untuk ayam kampung di Indonesia perlu diteliti. 
Tabel 1. Kebutuhan Gizi Ayam Kampung

\begin{tabular}{lccc}
\hline \multirow{2}{*}{$\begin{array}{c}\text { Kebutuhan } \\
\text { Gizi }\end{array}$} & $\mathbf{3}$ M-12 & $\mathbf{1 2 - 2 2}$ & $\begin{array}{c}\mathbf{2 2} \text { - ke } \\
\text { atas }\end{array}$ \\
\cline { 2 - 4 } & 2600 & 2400 & $2400-$ \\
Energi (\%) & & & 2600 \\
& $17-20$ & 14 & 14 \\
Protein (\%) & $4-7$ & $7-9$ & $7-9$ \\
$\begin{array}{l}\text { Serat kasar } \\
(\%)\end{array}$ & 0.9 & 1.00 & 3.4 \\
Kalsium & 0.45 & 0.45 & 0.34 \\
Phospor & 0.37 & 0.21 & $0.22-0.30$ \\
Methionin & & 0.45 & 0.68 \\
Lisin & 0.87 & 0
\end{tabular}

Kebutuhan gizi pada ternak tergantung pada umur, jenis kelamin, kecepatan pertumbuhan, fase produksi serta keadaan kesehatan ternak (Anggorodi, 1979). Sifat khusus unggas adalah mengkonsumsi ransum untuk memperoleh energi sehingga jumlah makanan yang dimakan tiap harinya berkecenderungan berhubungan erat dengan kadar energinya. Bila persentase protein yang tetap terdapat dalam semua ransum, maka ransum yang mempunyai konsentrasi $\mathrm{ME}$ tinggi akan menyediakan protein yang kurang dalam tubuh unggas karena rendahnya jumlah makanan yang di konsumsi dalam tubuh unggas. Sebaliknya, bila kadar energi kurang maka unggas akan mengkonsumsi makanan untuk mendapatkan lebih banyak energi akibatnya kemungkinan akan mengkonsumsi protein yang berlebihan (Tillman et al. 1991). Konsumsi pakan dipengaruhi oleh kuantitas dan kualitas ransum serta faktor-faktor lainnya seperti umur, palatabilitas, aktivitas ternak, tingkat produksi dan pengelolaannya.

\section{Rumusan Masalah}

Berdasarkan latar belakang tersebut maka inti permasalahan yang akan dikaji dalam penelitian ini adalah menganalisis kelayakan ekonomi usaha peternakan ayam kampung dengan menggunakan jus limbah wortel sebagai feed supplement.

\section{Tujuan Penelitian}

Tujuan dari penelitian ini adalah untuk mengetahui kelayakan ekonomi pemanfaatan jus limbah wortel sebagai feed supplement ayam kampung.

\section{Manfaat Penelitian}

1. Penelitian ini bermanfaat bagi masyarakat luas lebih khusus pada para peternak untuk mencoba memanfaatkan limbah sayur di pasar tradisional sebagai pakan tambahan untuk ternak ayam kampung.

2. Penelitian ini dapat memberikan informasi pada mahasiswa dan khalayak pengguna mengenai manfaat jus limbah wortel sebagai feed supplement ayam kampung.

\section{METODE PENELITIAN}

\section{Lokasi dan Waktu Penelitian}

Penelitian dilaksanakan pada bulan April sampai dengan bulan Juli 2019 di Kebun Percobaan Pandu Kabupaten Minahasa Utara.

\section{Materi Penelitian}

Ternak yang digunakan dalam penelitian adalah DOC ayam kampung sebanyak 80 ekor yang diperoleh dari Bintang Anugerah PS. Selama pemeliharaan fase starter ransum yang digunakan adalah konsentrat BR2. Minuman diberikan ad-libitum termasuk pemberian jus wortel dilakukan ketika ayam berumur 2 minggu. Buah wortel yang sudah layu diblender dengan penambahan air secukupnya, disaring untuk memisahkan serat dan cairan. Cairan berupa jus yang dihasilkan lalu dicampurkan ke dalam air minum perlakuan.

Bahan-bahan yang digunakan untuk menyusun ransum terdiri dari jagung kuning, dedak padi, konsentrat BR-2, topmix, yang dibeli dari poultry shop. Ransum yang digunakan selama penelitian adalah ransum formulasi berbentuk mash (bentuk tepung) dan scrumble (bentuk pecah/butiran). Adapun kandungan nutrisi bahan ransum dapat dilihat pada Tabel 1. 
Tabel 1. Komposisi Ransum Yang Digunakan Selama Penelitian

\begin{tabular}{lcccc}
\multicolumn{5}{c}{ Selama Penelitian } \\
\multicolumn{1}{c}{ Bahan } & W0 & W1 & W2 & W3 \\
\cline { 2 - 5 } & \multicolumn{4}{c}{$\%$} \\
\hline $\begin{array}{l}\text { Jagung } \\
\text { kuning }\end{array}$ & 49 & 49 & 49 & 49 \\
$\begin{array}{l}\text { Dedak } \\
\text { padi }\end{array}$ & 25 & 25 & 25 & 25 \\
$\begin{array}{l}\text { Konsentrat } \\
\text { BR2 }\end{array}$ & 25 & 25 & 25 & 25 \\
$\begin{array}{l}\text { Topmix } \\
\text { Jumlah }\end{array}$ & 1 & 1 & 1 & 1 \\
Jus Wortel & 0 & 100 & 100 & 100 \\
& & 20 & 40 & 80 \\
\hline
\end{tabular}

\section{Variabel Penelitian}

Analisis Ekonomi dilakukan analisis pendapatan untuk mengetahui pendapatan yang diperoleh dari usaha ternak tersebut dengan pemeliharaan ayam kampung. Menurut Soekartawi (2002), penerimaan adalah perkalian antara produksi dengan harga jual, biaya adalah semua pengeluaran yang dipergunakan dalam suatu usaha, dan pendapatan adalah selisih antara penerimaan dan pengeluaran.

Apabila nilai TR > TC maka usaha ternak menguntungkan, apabila $\mathrm{TR}=\mathrm{TC}$ maka usaha ternak dalam kondisi BEP, dan apabila TR < TC maka usaha ternak rugi (Pracoyo, 2006) dalam Putri et al, (2014).

Analisis kelayakan usaha meliputi BEP harga, BEP produksi dan $\mathrm{R} / \mathrm{C}$ ratio.

$$
\begin{aligned}
& \text { Break Event Point (BEP) harga } \\
& =\frac{\text { total biaya produksi }}{\text { total produksi }}
\end{aligned}
$$

Break Event Point (BEP) produksi $=\frac{\text { total biaya produksi }}{\text { harga jual per ekor }}$......(Munawir, 2002)

Revenue cost $(\mathrm{R} / \mathrm{C})$ ratio

$$
=\frac{\text { total pendapatan }}{\text { total biaya produksi }}
$$

$\mathrm{R} / \mathrm{C}$ ratio yaitu jumlah ratio yang dipakai untuk mengetahui sejauhmana hasil yang diperoleh dari usaha yang menguntungkan pada periode tertentu.
Analisis $\mathrm{R} / \mathrm{C}$ rasio dalam penelitian ini merupakan hasil dari perbandingan total penerimaan dan total biaya. Secara teoritis, apabila nilai $\mathrm{R} / \mathrm{C}>1$ maka usaha ternak efisien atau menguntungkan, apabila nilai $\mathrm{R} / \mathrm{C}$ = 1 maka usaha ternak dalam kondisi BEP, dan apabila nilai $\mathrm{R} / \mathrm{C}<1$ maka usaha ternak tidak efisien atau rugi.

\section{HASIL DAN PEMBAHASAN}

\section{Analisis Ekonomi}

Analisis ekonomi dilakukan terhadap analisis finansial terkait pengeluaran dan penerimaan selama 8 minggu. Biaya pengeluaran atau produksi meliputi DOC, pembelian pakan, vaksin, dan wortel. Komponen penerimaan adalah jumlah ayam per unit dikalikan dengan harga ayam saat penjualan. Pemberian pakan diberikan dengan jenis pakan yang sama hingga selesai penelitian. Hasil analisis ekonomi menunjukkan bahwa nisbah $\mathrm{R} / \mathrm{C}$ tertinggi diperoleh pada perlakuan W3 dan W2 dengan nilai sebesar 2,25 disusul perlakuan W1 sebesar 2,21 dan W0 sebesar 2,16. R/C pada W2 dan W3 artinya setiap penambahan biaya pengeluaran sebesar $\mathrm{Rp} / 2,-$ akan memberikan penerimaan sebesar Rp. 2,25,-.

Analisis BEP atau titik impas merupakan teknik analisa untuk mempelajari hubungan antara biaya total dan laba yang diharapkan dapat membantu mengetahui pada volume penjualan dan volume produksi berapakah suatu perusahaan tidak mengalami kerugian dan tidak pula mendapatkan keuntungan. Secara umum BEP adalah suatu keadaan dimana sebuah perusahaan tidak mengalami kerugian atau memperoleh keuntungan (Soekartawi, 1995). Artinya dalam kondisi ini jumlah penerimaan yang diterima sama dengan jumlah biaya yang dikeluarkan. Analisis BEP memberikan pedoman tentang berapa jumlah produk minimal yang harus di produksi atau dijual dan pada harga jual berapa tidak untung dan tidak rugi. 


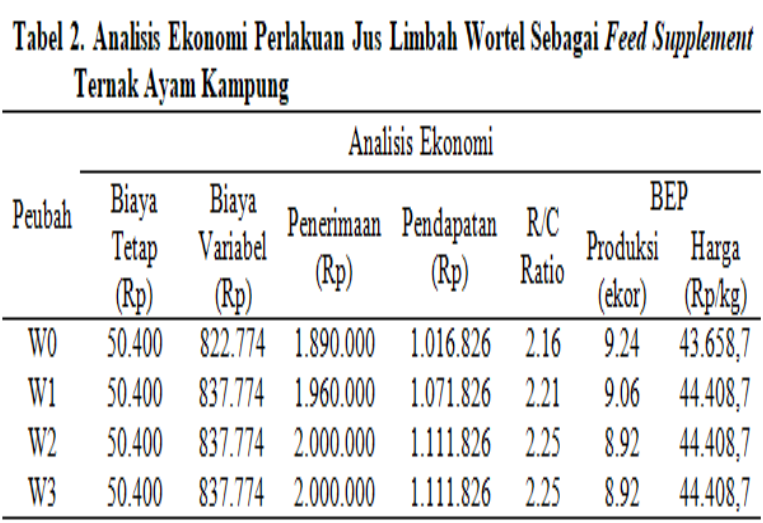

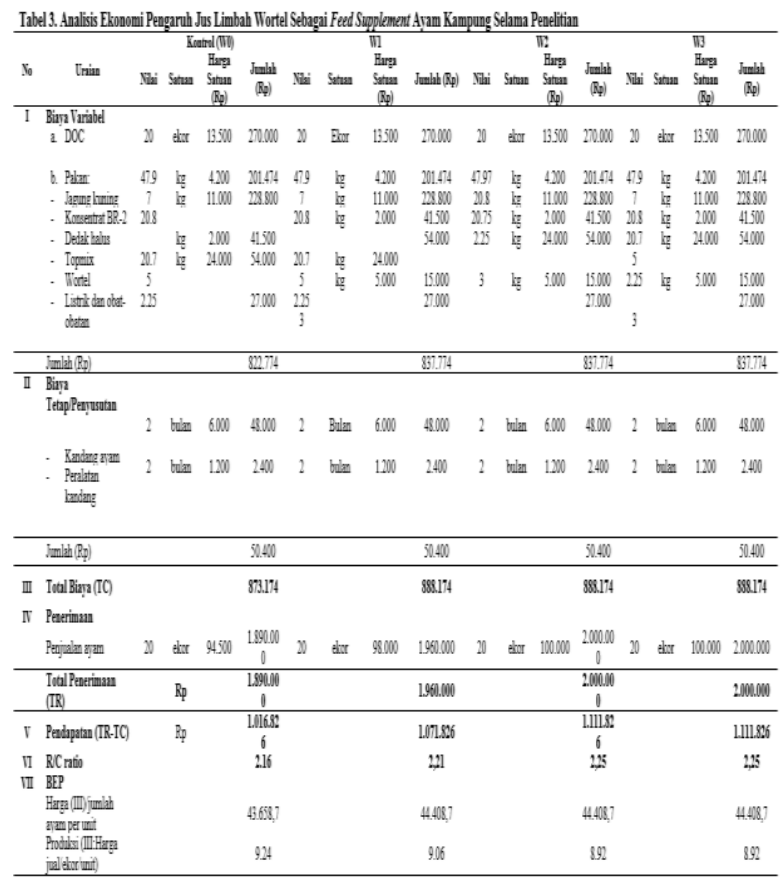

Berdasarkan tabel 3 di atas, biaya variabel pada perlakuan kontrol sebesar Rp. 822.774 sedangkan pada perlakuan jus wortel memiliki nilai yang sama yaitu Rp. 837.774. Penerimaan pada perlakuan kontrol sebesar Rp. 1.890.000, pendapatan sebesar Rp. 1.016.826. Perlakuan W1 mendapat penerimaan dari penjualan ayam sebesar Rp. 1.960.000 dan pendapatan Rp. 1.071.826. Berbeda dengan perlakuan W2 dan W3 penerimaan dan pendapatan sama nilainya yaitu sebesar Rp. 2.000.000. Pada Tabel 3 terlihat bahwa hasil penjualan per ekor berdasarkan bobot hidup yaitu Rp. 100.000/ekor. Hal ini menyebabkan $\mathrm{R} / \mathrm{C}$ ratio ke-2 perlakuan tersebut sama yaitu 2.25. Menurut Rahardi dan Hartanto (2003), bahwa suatu usaha dikatakan layak dan memberikan manfaat positif pada usaha itu apabila nilai suatu R/C >1 Rasio lebih besar dari satu (1).
Semakin besar nilai R/C Ratio maka usaha atau bisnis akan semakin menguntungkan, sebab penerimaan yang diperoleh produsen dari setiap pengeluaran biaya produksi sebesar 1 unit akan semakin besar (Fitriadi dan Nurmalina, 2008). Akan tetapi pada perlakuan W1 dan W0 dengan nilai $\mathrm{R} / \mathrm{C}$ ratio masih lebih besar dari 1, dapat dikatakan bahwa usaha ternak ayam kampung ini layak untuk diusahakan.

Angka BEP berdasarkan perhitungan menunjukkan bahwa titik impas produksi pada perlakuan W0 sebesar 9.24 ekor dan titik impas harga per ekor sebesar Rp. 43.658,7, sedangkan produksi ayam sebesar 20 ekor dengan harga jual ayam per ekor Rp. 94.500. Perlakuan W1 menunjukkan titik impas produksi 9.06 ekor dan titik impas harga per ekor sebesar Rp. 44.408,7 dengan harga jual ayam per ekor Rp. 98.000. Titik impas harga pada peerlakuan W2 dan W3 sama dengan W1 yaitu Rp. 44.408,7 dengan harga jual per ekor Rp. 100.000, sedangkan titik impas produksinya masingmasing memperoleh nilai yang sama yaitu 8.92 ekor. Dari penelitian ini dapat disimpulkan bahwa usaha ternak ayam kampung dengan memanfaatkan limbah wortel sebagai feed supplement dalam air minum ayam menguntungkan dan bisa dilanjutkan karena penghasilan dari produk dan rupiahnya mampu melebihi nilai Break Event Pointnya (BEP).

\section{KESIMPULAN DAN SARAN}

\section{Kesimpulan}

Pemanfaatan jus wortel layak digunakan sebagai feed supplement ternak ayam kampung karena memberikan keuntungan berdasarkan analisis ekonomi nilai $\mathrm{R} / \mathrm{C}>1$ maka usaha ternak tersebut efisien/menguntungkan dan Break Event Point yang dilampaui oleh penghasilan produk dan rupiahnya.

\section{Saran}

Usaha ternak ayam kampung yang memperhatikan faktor manajemen pemeliharaan yang baik dapat terhindar dari jumlah mortalitas yang besar dan bisa memperoleh keuntungan optimal. 


\section{DAFTAR PUSTAKA}

Anggorodi. 1979. Ilmu Makanan Ternak Umum. PT Gramedia. Jakarta.

Direktorat Jendral Peternakan, 2015. Buku Statistik Peternakan. Departemen Pertanian Republik Indonesia. Jakarta.

Fitriadi, F. dan R. Nurmalina, 2008. Analisis Pendapatan dan Pemasaran Padi Organik Metode System of Rice Intensification (SRI): Kasus di Desa Sukagalih, Kecamatan Sukaratu, Kabupaten Tasikmalaya). Jurnal Pengkajian dan Pengembangan Teknologi Pertanian. 11 (1): $94-103$.

Hardjosworo, P. S. dan Rukmiasih. 2000. Meningkatkan Produksi Daging Unggas. Penebar Swadaya. Depok.

Kusbandari, A. dan Susanti, H. 2017. Kandungan Beta Karoten Dan Aktivitas Penangkapan Radikal Bebas Terhadap Dpph (1,1-Difenil 2-Pikrilhidrazil) Ekstrak Buah Blewah (Cucumis Melo Var. Cantalupensis L) Secara Spektrofotometri UV Visibel. Jurnal Farmasi Sains Dan Komunitas. Vol. 14 No. 1: Hlm. 37-42.

Murtidjo, B, A. 1998. Mengelola Itik. Kanisius. Yogyakarta.

Murtidjo, B.A. 1985. Pedoman Meramu Pakan Unggas. Kanisius. Yogyakarta.

Munawir, S. (2002). Analisis Laporan Keuangan. Liberty. Yogyakarta.

Nawawi, N.T. dan Nurrohmah, S. 1997. Ransum Ayam Kampung. Trubus Agrisana. Surabaya.

NRC. 1994. Nutrien Requirements of Poultry. 9th ed. National Academy Press. Washington.D.C.

Putri, S.C. Suwandari, A. dan Mustapit. 2014. Analisis Pendapatan dan Kontribusi Usaha Ternak Ayam Buras Terhadap Pendapatan Keluarga serta Prospek Pengembangannya. Berkala Ilmiah Pertanian. hlm 1-10.

Rasyaf, M. 1992. Memelihara Ayam Buras. Kanisius. Yogyakarta.

Rasyaf, M. 2001. Beternak Ayam Pedaging. Cetakan Ke-XX. Penebar Swadaya. Jakarta.

Rahardi, F \& Hartanto, Rudi 2003, Agribisnis Peternakan. Penebar Swadaya. Jakarta.
Setioko, A.R. dan S. Iskandar. 2005. Review Hasil Hasil Penelitian dan dukungan Teknologi dalam Pengembangan Ayam Lokal. Prosiding Lokakarya Nasional Inovasi Teknologi Pengembangan Ayam Lokal. Semarang, 25 September 2005. Pusat penelitian dan Pengembangan Peternakan, Bogor. Hal. 10-19.

Scott, M.L. Nesheim, M.C., Young, R.J. 1982. Nutrition of chicken. ML Scott and Associates publishers, Ithaca, NY.

Soekartawi. 1995. Teori ekonomi produksi. Penerbit Rajawali. Jakarta.

Soekartawi. 2002. Prinsip Dasar Ekonomi Pertanian. Teori dan Aplikasi. Jakarta: Raja Grafindo Persada.

Setyanto, I. Atmomarsono, U. dan Muryani, R. 2012. Pengaruh Penggunaan Tepung Jahe Emprit (Zingiber Officinale Var Amarum) Dalam Ransum Terhadap Laju Pakan Dan Kecernaan Pakan Ayam Kampung Umur 12 Minggu. Animal Agriculture Journal, Vol. 1. No. 1, 2012, p $711-720$.

Sharma, K.K., Saikia, R., Kotoky, J., Kalita, J.C. \& Devi, R., 2011, Antifungal Activity of Solanum melongena L., Lawsonia inermis L., Justicia gendarussa B. against Dermatophytes, International Journal of Pharmtech Research, 3 (3), 1635-1640.

Tahalele, Y. E.R. Martina, Montong, Nangoy, F.J, Sarajar, C.L.K. 2018. Pengaruh Penambahan Ramuan Herbal Pada Air Minum Terhadap Persentase Karkas, Persentase Lemak Abdomen dan Persentase Hati pada Ayam Kampung Super. Jurnal Zootek Vol. 38. No. 1: $160-168$.

Tillman, A. D, H. Hartadi, S. Reksohadiprodjo, S. Prawirokusumo dan S. Lebdosukojo. 1991. Ilmu Makanan Ternak Dasar. Gadjah Mada University Press. Fakultas Peternakan. Universitas Gadjah Mada. Yogyakarta.

Winarsih, S., 2007. Mengenal dan Membudidayakan Buah Naga, CV Aneka Ilmu, Semarang.

Williamson, G. dan W. J. A. Payne. 1993. Pengantar Peternakan di Daerah Tropis (Diterjemahkan oleh S.G.N.D. Darmadja). Edisi ke-1. Gadjah Mada University Press. Yogyakarta. 